\title{
SEASONAL VARIATIONS IN BLOOD PARAMETERS AMONG KYRGYZ ELITE JUDO ATHLETES
}

\author{
VARIAÇÕES SAZONAIS DE ALGUNS PARÂMETROS SANGUIINEOS EM ATLETAS DE JUDÔ DEELITE \\ DO QUIRGUISTÃO
}

\author{
VARIACIONES ESTACIONALES DE ALGUNOS PARÁMETROS SANGUÍNEOS EN ATLETAS DE JUDO \\ DE KIRGUISTÁN
}

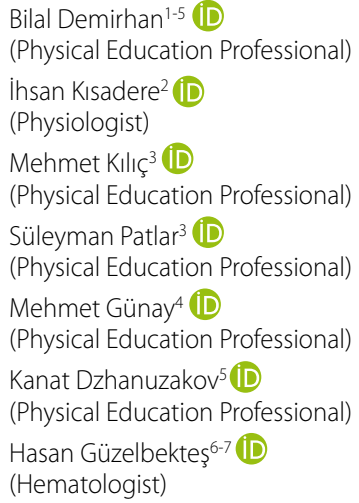

\section{Correspondence:}

Insan Kisadere,

Department of Physiology, Faculty of Veterinary Medicine,

University of Balikesir, 10100, Turkey. insan.kisadere@balikesir.edu.tr

\begin{abstract}
Introduction: Evaluation of health status and physical condition of Kyrgyz Judo Athletes before the Olympic Games. Objective: To evaluate changes in hematological, biochemical and blood gas values of athletes during the training period. Methods: Eight elite athletes ( $n=8$ men), participated to the study. Before and after the exercise periods (baseline, $3^{\text {rd }}$ month and $6^{\text {th }}$ month), blood samples were taken, to determine plasma red blood cell (RBC), white blood cell (WBC), blood clot cell (PLT), granulocyte (NOTR) and agranulocyte (LNF) counts, hemoglobin (HGB) and hematocrit (HCT) values, mean corpuscular volume (MCV), mean corpuscular hemoglobin concentration (MCHC), and venous blood $\mathrm{pH}, \mathrm{PO}_{2}, \mathrm{PCO}_{2}, \mathrm{SAT}_{2}, \mathrm{HCO}_{3}, \mathrm{BE}, \mathrm{Na}, \mathrm{K}, \mathrm{Cl}$ values. In addition, serum glucose (Glu), total protein (TP), total cholesterol (TC), HDL cholesterol, triglyceride (Trig), blood urea nitrogen (BUN), creatinine (Creat), lactate dehydrogenase (LDH) and creatine phosphokinase (CPK) values were measured. Results: Although, the athletes'WBC and LNF counts increased significantly $(p<0.05)$ in post-exercise periods, no statistical significance $(p>0.05)$ was found in the other hematological parameters. Blood $\mathrm{pH}, \mathrm{pCO}_{2}, \mathrm{HCO}_{3}$ and $\mathrm{BE}$ values decreased $(\mathrm{P}<0.05)$ after the exercise periods. Conclusion: The effects of exercise on judo athletes were evaluated before the Olympics. Level of Evidence III; Case-control study.
\end{abstract}

Keywords: Judo; Hematology; Biochemistry; Sports.

\section{RESUMO}

Introdução: Avaliação do estado de saúde e condição física dos atletas de judô do Quirguistão antes dos Jogos Olímpicos. Objetivo: Avaliar a alteração dos valores hematológicos, bioquímicos e gasométricos de atletas durante o período de treinamento. Métodos: Oito atletas de elite ( $n=8$ homens) participaram do estudo. Antes e depois dos períodos de exercício (basal, $3^{\circ}$ mês e $6^{\circ}$ mês), foram coletadas amostras de sangue para determinar as contagens de eritrócitos (RBC), leucócitos (WBC), plaquetas (PL), granulócitos (NOTR) e agranulócitos (LNF), hemoglobina (Hg) ehematócrito (Ht), volume corpuscular médio (VCM), concentração de hemoglobina corpuscular média (CHCM), valores de pH, $\mathrm{PO}_{21}, \mathrm{PCO}_{21}, \mathrm{SatO}_{21}, \mathrm{HCO}{ }_{3 \prime}, \mathrm{EB}, \mathrm{Na}, \mathrm{K}$ e Cl. Além disso, foram medidas as concentrações de glicemia (Gli), proteína total (PT), colesterol total (CT), HDL colesterol, triglicérides (TG), nitrogênio ureico no sangue (BUN), creatinina (Cr), lactato desidrogenase (LDH) e creatina fosfoquinase (CPK). Resultados: Embora a contagem de WBC e agranulócitos dos atletas tenham aumentado significativamente ( $p<$ $0,05)$ nos períodos pós-exercício, não foi encontrada significância estatística $(p>0,05)$ nos outros parâmetros hematológicos. Os valores de $\mathrm{pH}, \mathrm{pCO}_{2}, \mathrm{HCO}_{3}$ e EB diminuíram $(\mathrm{P}<0,05)$ depois dos períodos de exercício. Conclusões: Os efeitos do exercício em atletas de judô foram avaliados antes das Olimpíadas. Nível de Evidência III; Estudo de caso-controle.

Descritores: Judô; Hematologia; Bioquímica; Esportes.

\section{RESUMEN}

Introducción: Evaluación del estado de salud y condición física de los atletas de judo de Kirguistán antes de los Juegos Olímpicos. Objetivo: Evaluarla alteración de los valores hematológicos, bioquímicos y gasométricos de atletas duranteel periodo de entrenamiento. Métodos: Ocho atletas de élite ( $n=8$ hombres), participaron en el estudio. Antesy después de los períodos de ejercicio (basal, $3^{\circ}$ mes y $6^{\circ}$ mes), fueron colectadas muestras de sangre para determinar el conteo de eritrocitos (RBC), leucocitos (WBC), plaquetas (PLT), granulocitos (NOTR) y agranulocitos. (LNF), hemoglobina (Hg) y hematocrito (Ht), volumen corpuscular promedio (VCM), concentración de hemoglobina corpuscular promedio (CHCM), valores de $\mathrm{HH}_{1} \mathrm{PO}_{21}, \mathrm{PCO}_{21}, \mathrm{SatO}_{2,}, \mathrm{HCO}{ }_{3}, \mathrm{~EB}, \mathrm{Na}$, Ky Cl. Además, fueron medidas las concentraciones de glucemia (Gli), proteína total (PT), colesterol total (CT), HDL colesterol, triglicéridos (TG), nitrógeno ureico en la sangre (BUN), creatinina (Cr), lactato deshidrogenasa $(L D H)$ y creatina fosfoquinasa (CPK). Resultados: Aunque el conteo de WBC y agranulocitos de los atletas hayan aumentaron significativamente $(p<0,05)$ en los períodos post ejercicio, no fue encontrada significancia estadística ( $p>0.05$ ) en los otros parámetros hematológicos. Los valores de $\mathrm{pH}, \mathrm{pCO}_{2}, \mathrm{HCO}_{3}$ y EB disminuyeron $(P<0,05)$ después de los períodos de ejercicio. Conclusiones: Los efectos del ejercicio en atletas de judo fueron evaluados antes de las Olimpíadas. Nivel de Evidencia III; Estudio de caso-control.

Descriptores: Judo; Hematología; Bioquímica; Deportes. 


\section{INTRODUCTION}

Olympic Games is a great sporting and cultural event with the participation of elite athletes from many different countries around the world for competitions. All of the elite athletes want to compete in Olympics, and represent their country.'

One of the an important Olympic Sports is Judo. Judo is a martial art and sport included in Olympics since 1964. It requires power, high coordination, physical, cognitive and emotional control, and fast technical skills in relation to the opponent.,3 Besides, it requires specific aerobic and anaerobic fitness characteristics for the success in the exercise periods and also competitions. ${ }^{4}$

In preparation cycle towards an Olympic Games, athletes enter the extreme physical and mental preparation period for performing successful performance in competitions. ${ }^{1}$ During the preparation period, monitoring of the biochemical, hematological and blood gas parameters is an important indicator for the evaluation of the health status and performance of the athletes before the competitions by trainers and doctors. ${ }^{5}$

In the present study, we aimed to evaluate the changing of hematological, biochemical and blood gas values of the Kyrgyz Elite Judo Athletes who in the preparation period for the Olympic Games.

\section{METHODS}

Eight elite judo athletes ( $n=8$ men) participated in the study after full explanation of the objectives and written consent. The study protocol was approved by the ethics committee of Kyrgyzstan State Sports Academy Ethics Committee (No: 2015/175). The interval of regular practice, time (h) of daily practice and dietary routine were obtained through individual interviews and from trainers. All athletes were adults (mean age; $23.6 \pm 1.89$ years old), had a rigorous daily training program (5.0 \pm 0.3 $h$ /day), and were on the elite category for $4.0 \pm 2$ years, participating in national and international competitions. Elite judo athletes received an individualized diet for maintenance of adequate body composition for the sport modality during 6 months. During this study, the athletes did not use any vitamin or mineral supplements.

Body weight of the judo athletes was measured with a portable scale (Angel, USA) to the nearest $0.02 \mathrm{~kg}$. Besides, the height (HT) values of the athletes were measured with a stadiometer (Holtain, UK) to the nearest $1 \mathrm{~mm}$.

Before and after the exercise periods, blood samples were collected from Kyrgyz National Judo Athletes by cephalical vein via needle $(1.2 \mathrm{~mm} \times 38 \mathrm{~mm})$ to normal and heparinized tubes, then transferred to biochemical lab of Kyrgyz-Turkish Manas University Research Center under cold chain, and centrifuged at $3000 \mathrm{~g}$ for 20 min in January, May and July. Heparinised venous blood samples also transferred to the biochemical lab immediately after the collections. Serum and plasma samples were retained in Eppendorf tubes until analysis time in a refrigerator $\left(-20^{\circ} \mathrm{C}\right)$.

Plasma red blood cell (RBC), white blood cell (WBC), blood clot cell (PLT),granulocytes (NOTR) and agranulocytes (LNF) counts, hemoglobin (HGB) and hematocrit (HCT) values, mean corpuscular volume (MCV), mean corpuscular hemoglobin concentration (MCHC)were measured in the blood plasma samples by using automated biochemistry analyzer (BC-2300, Mindray, China).

Venous blood $\mathrm{pH}, \mathrm{PO}_{2}, \mathrm{PCO}_{2}, \mathrm{SATO}_{2}, \mathrm{HCO}_{3}, \mathrm{BE}, \mathrm{Na}, \mathrm{K}, \mathrm{Cl}$ values were detected from heparinised blood samples by using Electrolyte and Blood Gas Analyzer (IDEXX Vetstat, USA).

Serum glucose (Glu), total protein (TP), total cholesterol (TC), HDL cholesterol, triglyceride (Trig), blood urea nitrogen (BUN), creatinine (Creat), lactate dehydrogenesis ( $\mathrm{LDH}$ ) and creatinin phosphokinase (CPK) analyzes were performed by using auto analyzer (Mindray Perfect Plus 400, China).

\section{Statistical analysis}

Data were analyzed by using SPSS version 21.0 software (SPSS, Inc., Chicago, IL, USA) computer package program. Single Sample Kolmogorov-Smirnov test was performed to determine the homogeneity of the data. Variance Analysis was also used for determining the differences between all three repeated measurements. Besides, Paired t-test was also used for binary measurements. A $p$ - value $<0.05$ was considered statistically significant.

\section{RESULTS}

The average body weight and the height $(\mathrm{HT})$ of the judo athletes were shown in Table 1. Although, WBC and LNF counts of the elite judo athletes significantly increased $(p<0.05)$ in post-exercise periods when compared to pre-exercise, it was not found statistical significance ( $p>0.05$ ) in another hematological parameters according to the pre and post-exercise periods in all measurements (baseline, $3^{\text {rd }}$ month and $6^{\text {th }}$ month), shown in Table 2. In the analysis of biochemical data of judo athletes, the concentration of HDL cholesterol significantly increased $(p<0.05)$, however Glu concentration was significantly $(p<0.05)$ decreased in post-exercise period (baseline, $3^{\text {rd }}$ month and $6^{\text {th }}$ month) when compared to pre-exercise in all measurements (baseline, $3^{\text {rd }}$ month and $6^{\text {th }}$ month) $(p<0.05)$. LDL-cholesterol concentrations of the athletes significantly decreased $(p<0.05)$ in the post-exercise period of first and third measurements (baseline and $6^{\text {th }}$ month). In addition, Creat and CK enzyme activities significantly increased $(p<0.05)$ in the post-exercise period when compared to pre-exercise only in the first measurements (baseline). Besides, there was no significant change according to mentioned biochemical parameters between the pre and post-exercise periods ( $p>0.05$ ). No statistically significant difference was observed between the pre and post-exercise periods according to biochemical parameters in three measurements which was performed in the elite judo athletes ( $p>0.05$ ), shown in Table 3. Venous blood $\mathrm{pH}, \mathrm{pCO} 2, \mathrm{HCO} 3$ and $\mathrm{BE}$ values decreased significantly $(p<0.05)$, however, $\mathrm{pO}_{2}, \mathrm{O}_{2} \mathrm{SAT}$, Kand Anion Gap values increased $(p<0,05)$ after the exercise periods. It was not observed any significant change in $\mathrm{Na}$ and $\mathrm{Cl}$ levels in all measurements. In addition, there was no statistically significant difference between the values of venous blood gase before and after the exercise periods in first and second measurements (6 months later), shown in Table 4.

Table 1. Average age, height and weight characteristics of the Elite Judo Athletes.

\begin{tabular}{c|c|c|c}
\hline $\mathbf{N}$ & $\begin{array}{c}\text { Age (year) } \\
\text { Mean } \pm \text { SD }\end{array}$ & $\begin{array}{c}\text { Height }(\mathbf{c m}) \\
\text { Mean } \pm \text { SD }\end{array}$ & $\begin{array}{l}\text { Weight }(\mathbf{k g}) \\
\text { Mean } \pm \text { SD }\end{array}$ \\
\hline 8 & $23.6 \pm 1.89$ & $175.7 \pm 36,87$ & $86.2 \pm 20.27$ \\
\hline
\end{tabular}

Demographic characteristics of Kyrgyz elite judo athletes are mentioned above.

\section{DISCUSSION}

Judo is a martial art and sport which requires a great contribution to anaerobic metabolism. There are many changes on the physical, hematological and biochemical characteristics of the elite judo athletes, who expose to more anaerobic occasion, in preparation periods according to exercise. ${ }^{6}$

The counts of the WBC, LNF and NOTR were detected higher in post-exercise periods (baseline, 3. and 6. months) when compared to pre-exercise in the present study. The level of WBC was also detected higher immediately after (30 minutes later) exercise period in judo athletes by Heidari et al.. ${ }^{7}$ It is known that physical activities can cause significant changes in the number and distribution of WBCs in bloodstream. ${ }^{8} \mathrm{HGB}, \mathrm{HCT}$ and MCV values also increased in all post-exercise periods depend on training in this study. Besides, HGB and MCV levels of the judo athletes were observed improve due to the exercise program 
Table 2. Average hematological parameters of the Elite Judo Athletes at different periods.

\begin{tabular}{|c|c|c|c|c|c|c|c|c|c|}
\hline \multirow{2}{*}{$\begin{array}{l}\text { Parameters } \\
(n=8)\end{array}$} & \multicolumn{2}{|c|}{$\begin{array}{l}\text { I. analysis } \\
\text { (Baseline) }\end{array}$} & \multicolumn{3}{|c|}{$\begin{array}{c}\text { II. analysis } \\
\text { (3 months later) }\end{array}$} & \multicolumn{3}{|c|}{$\begin{array}{c}\text { III. analysis } \\
\text { (6 months later) }\end{array}$} & \multirow[b]{2}{*}{$P$} \\
\hline & $\begin{array}{c}\text { PR-EX } \\
(\text { Mean } \pm \text { SD) }\end{array}$ & $\begin{array}{c}\text { PO-EX } \\
(\text { Mean } \pm \text { SD) }\end{array}$ & $P$ & $\begin{array}{c}\text { PR-EX } \\
(\text { Mean } \pm \text { SD) }\end{array}$ & $\begin{array}{c}\text { PO-EX } \\
(\text { Mean } \pm \text { SD) }\end{array}$ & $\mathbf{P}$ & $\begin{array}{c}\text { PR-EX } \\
(\text { Mean } \pm \text { SD) }\end{array}$ & $\begin{array}{c}\text { PO-EX } \\
(\text { Mean } \pm \text { SD) }\end{array}$ & \\
\hline WBC $\left(10^{9} / L\right)$ & $5.96 \pm 0.99$ & $10.26 \pm 2.11$ & **** & $6.00 \pm 2.42$ & $8.90 \pm 3.25$ & *** & $5.60 \pm 1.56$ & $9.48 \pm 1.81$ & *** \\
\hline $\operatorname{LNF}\left(10^{9} / \mathrm{L}\right)$ & $1.92 \pm 0.39$ & $4.30 \pm 1.01$ & **** & $1.68 \pm 0.53$ & $3.55 \pm 0.92$ & & $1.80 \pm 0.28$ & $3.10 \pm 0.99$ & $*$ \\
\hline $\operatorname{NOTR}\left(10^{9} / \mathrm{L}\right)$ & $3.40 \pm 1.08$ & $4.63 \pm 1.40$ & & $3.97 \pm 1.74$ & $4.95 \pm 2.29$ & & $4.93 \pm 0.91$ & $5.53 \pm 0.89$ & \\
\hline $\mathrm{HGB}(\mathrm{g} / \mathrm{dl})$ & $15.32 \pm 1.03$ & $17.27 \pm 0.66$ & & $15.80 \pm 3.13$ & $18.35 \pm 3.57$ & & $15.28 \pm 2.65$ & $18.40 \pm 2.42$ & \\
\hline $\mathrm{RBC}\left(10^{12} / \mathrm{L}\right)$ & $5.78 \pm 0.39$ & $6.11 \pm 0.36$ & & $6.23 \pm 1.14$ & $7.14 \pm 1.34$ & & $7.14 \pm 0.71$ & $6.94 \pm 1.11$ & \\
\hline HCT (\%) & $42.43 \pm 2.00$ & $44.90 \pm 2.62$ & & $46.68 \pm 10.68$ & $50.88 \pm 12.11$ & & $42.05 \pm 10.28$ & $50.00 \pm 10.59$ & \\
\hline MCV (fL) & $78.96 \pm 3.23$ & $79.84 \pm 3.49$ & & $81.00 \pm 2.08$ & $82.35 \pm 1.86$ & & $80.30 \pm 3.72$ & $82.42 \pm 3.32$ & \\
\hline $\mathrm{MCH}(\mathrm{pg})$ & $28.47 \pm 0.61$ & $28.35 \pm 0.80$ & & $28.55 \pm 0, .8$ & $28.48 \pm 0.70$ & & $27.75 \pm 1.43$ & $27.68 \pm 1.17$ & \\
\hline $\mathrm{MCHC}(\mathrm{g} / \mathrm{dl})$ & $31.72 \pm 0.46$ & $31.13 \pm 0.58$ & & $31.42 \pm 0.55$ & $30.88 \pm 0.49$ & & $30.88 \pm 0.7$ & $31.30 \pm 0.98$ & \\
\hline $\mathrm{PLT}\left(10^{9} / \mathrm{L}\right)$ & $271.83 \pm 23.73$ & $290.50 \pm 20.08$ & & $194.00 \pm 57.65$ & $199.33 \pm 97.89$ & & $214.33 \pm 40.39$ & $253.67 \pm 85.16$ & \\
\hline
\end{tabular}

Table 3. Biochemical parameters of the Elite Judo Athletes at different periods.

\begin{tabular}{|c|c|c|c|c|c|c|c|c|c|}
\hline \multirow{2}{*}{$\begin{array}{l}\text { Parameters } \\
\qquad(n=8)\end{array}$} & \multicolumn{3}{|c|}{$\begin{array}{l}\text { I. analysis } \\
\text { (Baseline) }\end{array}$} & \multicolumn{3}{|c|}{$\begin{array}{c}\text { II. analysis } \\
\text { (3 months later) }\end{array}$} & \multicolumn{2}{|c|}{$\begin{array}{c}\text { III. analysis } \\
\text { (6 months later) }\end{array}$} & \multirow[b]{2}{*}{$\mathbf{P}$} \\
\hline & $\begin{array}{c}\text { PR-EX } \\
(\text { Mean } \pm S D)\end{array}$ & $\begin{array}{c}\text { PO-EX } \\
(\text { Mean } \pm S D)\end{array}$ & $\mathbf{P}$ & PR-EX (Mean $\pm S D)$ & $\begin{array}{c}\text { PO-EX } \\
(\text { Mean } \pm S D)\end{array}$ & $\mathbf{P}$ & PR-EX (Mean \pm SD) & $\begin{array}{c}\text { PO-EX } \\
(\text { Mean } \pm S D)\end{array}$ & \\
\hline Glucose $(\mathrm{mg} / \mathrm{dl})$ & $91.17 \pm 14.16$ & $82.38 \pm 9.24$ & $*$ & $119.22 \pm 17.91$ & $85.60 \pm 5.70$ & $*$ & $113.55 \pm 8.33$ & $89.73 \pm 3.93$ & $*$ \\
\hline T.cholesterol(mg/dl) & $186.18 \pm 9.07$ & $187.15 \pm 13.38$ & & $191.12 \pm 11.24$ & $199.23 \pm 7.63$ & & $194.38 \pm 13.11$ & $196.93 \pm 17.33$ & \\
\hline HDL cholesterol (mg/dl) & $54.67 \pm 10.42$ & $71.17 \pm 11.60$ & $* * *$ & $60.17 \pm 14.16$ & $77.33 \pm 9.20$ & **** & $49.67 \pm 13.59$ & $63.83 \pm 10.93$ & **** \\
\hline LDL Kolesterol (mg/dl) & $131.67 \pm 11.41$ & $116.00 \pm 21.48$ & $*$ & $131.00 \pm 22.45$ & $122.00 \pm 10.49$ & & $144.67 \pm 24.91$ & $133.00 \pm 26.15$ & * \\
\hline Triglycerides(mg/dl) & $124.83 \pm 27.48$ & $134.67 \pm 19.15$ & & $171.83 \pm 35.52$ & $170.00 \pm 49.11$ & & $120.00 \pm 8.29$ & $140.33 \pm 21.32$ & \\
\hline T. Protein(g/dl) & $6.50 \pm 3.23$ & $6.70 \pm 0.15$ & & $6.57 \pm 0.39$ & $7.05 \pm 0.47$ & & $6.33 \pm 0.36$ & $6.96 \pm 0.43$ & \\
\hline Urea(mg/dl) & $23.25 \pm 5.37$ & $26.70 \pm 5.74$ & & $25.25 \pm 7.84$ & $28.15 \pm 9.62$ & & $24.03 \pm 7.69$ & $27.45 \pm 8.21$ & \\
\hline Creatinine $(\mathrm{mg} / \mathrm{dl})$ & $0.80 \pm 0.05$ & $0.91 \pm 0.08$ & * & $0.94 \pm 0.39$ & $1.06 \pm 0.44$ & & $0.90 \pm 0.16$ & $0.93 \pm 0.22$ & \\
\hline $\mathrm{CK}(\mathrm{U} / \mathrm{L})$ & $132.23 \pm 37.24$ & $189.20 \pm 64.88$ & * & $133.33 \pm 73.59$ & $136.33 \pm 50.03$ & & $127.33 \pm 39.28$ & $147.67 \pm 40.13$ & \\
\hline $\mathrm{LDH}(\mathrm{U} / \mathrm{L})$ & $260.00 \pm 38.50$ & $317.50 \pm 57.18$ & & $299.80 \pm 71.36$ & $339.80 \pm 72.45$ & & $274.20 \pm 21.81$ & $330.40 \pm 19.45$ & \\
\hline
\end{tabular}

${ }^{*} P<0,05 ;{ }^{*} P<0,01 ;{ }^{* *} * P<0,001$; was considered statistically significant in the same line. PR-EX: Pre-exercise; PO-EX: Post-exercise.

Table 4. Blood gases levels of the Elite Judo Athletes at different periods.

\begin{tabular}{|c|c|c|c|c|c|c|}
\hline \multirow{2}{*}{$\begin{array}{l}\text { Parameters } \\
\qquad(n=8)\end{array}$} & \multicolumn{2}{|c|}{$\begin{array}{l}\text { I. analysis } \\
\text { (Baseline) }\end{array}$} & \multirow[b]{2}{*}{$\mathbf{P}$} & \multicolumn{2}{|c|}{$\begin{array}{c}\text { II. analysis } \\
\text { (6 months later) }\end{array}$} & \multirow[b]{2}{*}{$\mathbf{P}$} \\
\hline & $\begin{array}{c}\mathrm{BE} \\
(\text { Mean } \pm \text { SD) }\end{array}$ & $\begin{array}{c}\mathrm{AE} \\
(\text { Mean } \pm \mathrm{SD})\end{array}$ & & $\begin{array}{c}\mathrm{BE} \\
(\text { Mean } \pm \mathrm{SD})\end{array}$ & $\begin{array}{c}\mathrm{AE} \\
(\text { Mean } \pm S D)\end{array}$ & \\
\hline $\mathrm{pH}$ & $7.37 \pm 0.06$ & $7.29 \pm 0.05$ & $*$ & $7.37 \pm 0.03$ & $7.28 \pm 0.04$ & * \\
\hline $\mathrm{PCO}_{2}$ & $51.50 \pm 9.11$ & $42.25 \pm 9.14$ & $*$ & $50.50 \pm 4.73$ & $44.50 \pm 7.33$ & * \\
\hline $\mathrm{PO}_{2}$ & $46.25 \pm 3.86$ & $58.00 \pm 10.54$ & $*$ & $48.01 \pm 5.24$ & $60.75 \pm 12.15$ & * \\
\hline $\mathrm{HCO}_{3}$ & $27.25 \pm 1.00$ & $18.55 \pm 1.99$ & * & $25.48 \pm 2.89$ & $21.56 \pm 4.56$ & ${ }^{*}$ \\
\hline $\mathrm{BE}$ & $0.85 \pm 1.56$ & $-6.73 \pm 0.87$ & * & $0.30 \pm 1.02$ & $-5.40 \pm 2.91$ & * \\
\hline $\mathrm{O}_{2} \mathrm{SAT}$ & $56.90 \pm 2.16$ & $67.50 \pm 14.62$ & * & $58.00 \pm 0.01$ & $68.25 \pm 7.97$ & * \\
\hline $\mathrm{K}$ & $3.38 \pm 0.50$ & $3.99 \pm 0.22$ & * & $3.4 \pm 0.35$ & $3.94 \pm 0.46$ & * \\
\hline $\mathrm{Na}$ & $140.02 \pm 0.82$ & $141.25 \pm 1.50$ & & $140.01 \pm 1.63$ & $141.00 \pm 2.94$ & \\
\hline $\mathrm{Cl}$ & $107.75 \pm 0.50$ & $108.00 \pm 2.71$ & & $106.50 \pm 1.00$ & $107.50 \pm 1.29$ & \\
\hline Anyon Gap & $8.65 \pm 0.95$ & $18.33 \pm 0.20$ & * & $10.67 \pm 2.21$ & $15.63 \pm 4.68$ & * \\
\hline
\end{tabular}

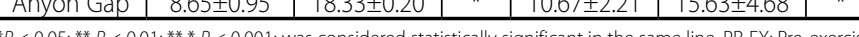

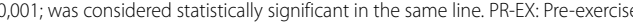
PO-EX: Post- exercise.

in the last exercise measurements. In contrary, it was reported that decreased HCT in response to strenuous physical exercises, and possibly associated with a decrease in plasma volume. ${ }^{9}$ Hence many factors such as environmental condition, diet, fasting, drugs administration might be affected on different datas. ${ }^{10}$ Although, RBC values of the judo athletes were found higher in two post-exercise periods (baseline and 3. months) when compared to pre-exercise, decreased after the exercise in III. (6. months later) analysis. When our findings were similar with Heidari et al. ${ }^{7}$ it was not consistent with the results of Cesur et al..1 ${ }^{11}$ It can be occurred due to the high blood pressure and intravascular hemolysis depends on high intensity exercise or differences in altitude of the training area. MCH and MCHC levels did not affected from high intensity exercise in present study. PLT values of the judo athletes also increased due to extensive exercise in all post-exercise periods (baseline, 3. and 6. months) in present study. Besides, an interesting fluctuations was observed in PLT values during the baseline, $3^{\text {rd }}$ and $6^{\text {th }}$ analysis in present study. Our findings were consistent with Heidari et al. ${ }^{7}$ but in conflict with results of Ahmadizad et al.. ${ }^{9}$ It may be attributed due to release of fresh platelets from the spleen, bone marrow, or from other reservoirs depends on secretion of epinephrine. ${ }^{7,12}$

Serum Glu levels of the judo athletes decreased in all post-exercise periods when compared to pre-exercise in the present study. Our findings were in agreement with Umeda et al. ${ }^{13}$ according to blood Glu levels. It was observed an increase in plasma Glu levels after a wrestling match by Karninčić et al. ${ }^{14}$ in cadets, and Mirzaei et al. ${ }^{15}$ in senior males. Besides, Andreato et al. ${ }^{16}$ did not detect any significant change in serum Glu levels after Jiu-Jitsu exercise. It can be explained by the exercise no reflect the rise in catecholamine levels, that cause rise in hepatic glucose production. ${ }^{17,18}$ The absence of changes in blood Glu can be explained by the fact that homeostatic metabolic pathways maintain stable levels of plasma glucose and liver and muscle glycogenolysis. ${ }^{19}$ Serum LDH levels were defined higher in all post-exercise periods when compared to pre-exercise in our study. Besides, LDH levels fluctuated during the measurement periods (from baseline to $3^{\text {th }}$ measurements). These results were also found similar with ours by Stavrinou et al..20 The augmentations of blood lactate concentration can be indicated the activation of glycolytic pathway. An another important factors for the evaluation of the muscle damage are CK and Creat levels were also determined the highest in all post-exercise periods in the present study. Chishaki et al. ${ }^{21}$ and Tartibian et al. ${ }^{22}$ also found the same results in judo athletes after training periods. It may be occurred due to long duration or intensity of judo training or not enough recovery. ${ }^{22}$ Total protein and urea levels of the judo athletes insignificantly increased depend on exercise in all measurements of the present study. Results of this study were in agreement with the findings of previous studies. ${ }^{23,24}$ It might be attributed to the extent of tissue damage-induced acute phase reaction and/ or a significant increase in plasma fibrinogen levels in judo athletes. Although serum T.chol and HDL cholesterol levels increased after the exercises, LDL cholesterol levels decreased during all measurements in the present study. It was observed a contradiction between the results of Trivic et al. ${ }^{5}$ and ours according to serum HDL and LDL levels. Degoutte et al. ${ }^{23}$ also found same results 
according to T. cholesterol and HDL levels after a judo match, however, no modifications in LDL-C were noted. Limited information is available on the effect of anaerobic exercise on blood lipid concentrations. ${ }^{25}$ It may be changed due to sex difference. The levels of the triglycerides were fluctuated according to the analysis periods in the present study. It was observed higher in baseline and $3^{\text {th }}$ but lower in $2^{\text {th }}$ analysis in post-exercise periods. Degoutte et al. ${ }^{23}$ also detected increased triglyceride levels 3 min after a judo match. In contrary, Andreato et al. ${ }^{18}$ and Stavrinou et al. ${ }^{20}$ determined no significant change in triglyceride levels which in conflict with our results. This different results can be occurred due to changing of activation in lipolysis and fat metabolism.

In first measurements before the exercise processes, we detected normal $\mathrm{pH}, \mathrm{BE}, \mathrm{HCO}_{3}, \mathrm{Na}, \mathrm{Cl}, \mathrm{K}$, but higher $\mathrm{PCO}_{2}$, lower $\mathrm{PO}_{2}$ and $\mathrm{O}_{2} \mathrm{SAT}$ levels in judo athletes when compared to normal human physiological ranges. ${ }^{26}$ It must be depending on the high altitude of the exercise area. Although blood $\mathrm{pH}$ and $\mathrm{PCO}_{2}$ levels of the judo athletes decreased after the exercises, $\mathrm{PO}_{2}$ levels were significantly increased in two measurements (baseline and 6 months later) in the present study. Anyon Gap also increased significantly after the exercise in two measurements. The same results were also detected by Hopkins et al..$^{27}$ in athletes who performed heavy exercise process. It must be observed depend on the occurring of metabolic acidosis due to an accumulation of the lactic acid and $\mathrm{H}^{+}$ions in blood during the anaerobic exercise. ${ }^{28}$ Although $\mathrm{O}_{2} \mathrm{SAT}$ of the judo athletes also significantly increased after the exercise periods, $\mathrm{BE}$ and $\mathrm{HCO}_{3}$ levels significantly decreased after exercises in this study. It may be explained by increasing of alveolar ventilation and using bicarbonate $\left(\mathrm{HCO}_{3}\right)$ by body to compensate the falling of $\mathrm{pH}$ and remove $\mathrm{H}^{+}$ions from the body of athletes after the exercise periods. ${ }^{29}$ Sodium $(\mathrm{Na})$ and chloride $(\mathrm{Cl})$ as the primary extracellular cations in the extracellular space, is lost to the greatest extent. On the other hand potassium $(\mathrm{K})$ is the primary intracellular cation. In our study, K levels significantly whereas $\mathrm{Cl}$ and $\mathrm{Na}$ levels insignificantly increased in judo athletes after the exercise periods. It is known that a decrease due to high-intensity exercise in $\mathrm{NaCl} /$ extracellular fluid/blood volume and, hence, arterial blood pressure stimulates the renin-angiotensin-aldosterone system. The end result is an increase in salt retention, which in turn increases water retention and elevates arterial pressure in the body. ${ }^{30}$

\section{CONCLUSION}

Consequently, some hematological, biochemical and blood gas values of the judo athletes were determined, and effects of the exercise periods on judo athletes were evaluated before the Olympics.

\section{ACKNOWLEDGMENTS}

This article has been produced from Kyrgyz Turkish Manas University's KTMU-BAP 2015.FBE.06 scientific research project. The Project was supported by the Olympic Sports Directorate of the Ministry of Sports of Kyrgyzstan and Bishkek Coordinator of Turkish Cooperation and Coordination Agency (TIKA).

All authors declare no potential conflict of interest related to this article

AUTHORS' CONTRIBUTIONS: Each author made significant individual contributions to this manuscript. MK, IK and BD: were responsible for data collection, data analysis and interpretation, and the writing of the draft; SP and HG: helped with statistical analysis and writing of the manuscript; MG and KC: designed the study and supervised the data collection, analysis, and supervised the writing of the manuscript. All authors read and approved the final manuscript.

\section{REFERENCES}

1. Franchini E, Takito MY. Olympic preparation in Brazilian judo athletes: description and perceived relevance of training practices. J Strenth Cond Res. 2014;28(6):1606-12.

2. Thomas SG, Cox MH, LeGal YM, Verde TJ, Smith HK. Physiological profiles of the Canadian National Judo Team. Can J Sport Sci. 1989;14(3):142-7.

3. Torres-Luque G, Hernández-García R, Escobar-Molina R, Garatachea N, Nikolaidis PT. Physical and Physiological Characteristics of judo athletes: an update. Sports (Basel). 2016;4(1):20.

4. Franchini E, Del Vecchio FB, Matsushigue KA, Artioli GG. Physiological profiles of elite judo athletes. Sports Med. 2011:41(2):147-66

5. Trivic T, Radjo I, Tabakov S, Mekic A, Drid P. Influence of exercise on blood lipids and immune system in female Serbian judokas. Health Med. 2011;5(5):1287-92.

6. Degoutte F, Jouanel P, Bègue RJ, Colombier M, Lac G, Pequignot JM, et al. Food restriction, performance, biochemical, psychological, and endocrine changes in judo athletes. Int J Sports Med. 2006;27(1):9-18.

7. Heidari $N$, Dortaj $E$, Karimi M, Karami S, Kordi N. The effects of acute high intensity interval exercise of judo on blood rheology factors. Turk J Kin. 2016;2(1):6-10.

8. El-Sayed MS, Ali N, Ali ZE. Haemorheology in exercise and training. Sports Med. 2005;35(8):649-70.

9. Ahmadizad S, El-Sayed MS, MacLaren DP. Effects of time of day and acute resistance exercise on platelet activation and function. Clin Hemorheol Microcirc. 2010;45(2-4):391-9.

10. Vecerek V, Strakova E, Suchy P, Voslarova E. Influence of high environmental temperature on production and haematological and biochemical indexes in broiler chickens. Czech J Anim Sci. 2002;47(5):176-82.

11. Cesur G, Atay E, Ogut S, Polat M, Ongel K. Effect of indoor climbing exercise on plasma oxidative stress, hematological parameters and heart rate responses in sedentary individuals. Biomed Res. 2012;23(4):566-70.

12. Garai B, Chatterjee S, Mondal S, Mondal T. Effect of exercise on platelet variables: an overview. Int J Phys Educ Sports Health. 2017;4(3):506-10.

13. Umeda T, Yamai T, Takahashi I, Kojima A, Yamamoto Y, Tanabe M, et al. The effects of a two-hour judo training session on the neutrophil immune functions in university judoists. Luminescence. 2008;23(1):49-53.

14. Karninčić H, Tocilj Z, Uljević O, Erceg M. Lactate profil during Greco-Roman wrestling match. J Sports Sci Med. 2009;8(CSSI3):17-9

15. Mirzaei B, Curby DG, Barbas I, Lotfi N. Physical fitness measures of cadet wrestlers. Int J Wrestl Sci. 2011;1:1.
16. Andreato LV, Moraes SM, Esteves JV, Pereira RR, Gomes TL, Andreato TV, et al. Physiologıcal responses and rate of perceived exertion in Brazilian Jiu-Jitsu athletes. Kinesiology. 2012;44(2):173-81.

17. Adam M, Smaruj M, Tabakov S, Blach L. Characteristics of the technical-tactical preparation of male and female competitors participating in the Olympic Games London 2012. J Martial Arts Anthrop. 2013;13(2):75-88

18. Andreato LV, Santos JF, Esteves JV, Panissa VL, Julio UF, Franchini E. Physiological, Nutritional and Performance Profiles of Brazilian Jiu-Jitsu Athletes. J Hum Kinetic 2016;53:261-71.

19. Febbraio MA, Dancey J. Skeletal muscle energy metabolism during prolonged, fatiguing exercise. J Appl Physiol (1985). 1999;87(6):2341-7.

20. Stavrinou SP, Argyrou M, Hadjicharalambous M. Physiological and metabolic responses during a simulated judo competition among cadet athletes. Int J Perf Anal Sport. 2016;16(3):848-59.

21. Chishaki T, Umeda T, Takahashi I, Matsuzaka M, Iwane K, Matsumoto $H$, et al. Effects of dehydration on immune functionsafter a judo practice session. Luminescence. 2013;28(2):114-20.

22. Tartibian B, Nouri H, Azadpour N, Kosar SN, Massart A, Filaire E. Eight weeks judo training in creases oxidative stress biomarkers and creatine kinase in male judoka. Indian J Biochem Biophys. 2015;52(5-6):281-8.

23. Degoutte $F$, Jouanel P, Filaire E. Energy demands during a judo match and recovery. Br J Sports Med. 2003;37(3):245-9.

24. Hung W, Liu TH, Chen CY, Chang CK. Effect of $\beta$-hydroxy- $\beta$-methylbutyrate supplementation during energy restriction in female judo athletes. J Exerc Sci Fit. 2010;8(1):50-3.

25. Berger GM, Griffiths MP. Acute effects of moderate exercise on plasma lipoprotein parameters. Int J Sports Med. 1987;8(5):336-41

26. Aygencel G. Interpretation of arterial blood gases. Turk Kardiol Dern Ars. 2014; 42(2):194-202.

27. Hopkins SR, Gavin TP, Siafakas NM, Haseler LJ, Olfert IM, Wagner H, et al. Effect of prolonged, heavy exercise on pulmonary gas exchange in athletes. J Appl Physiol (1985). 1998;85(4):1523-32

28. Hermansen L, Osnes JB. Blood and muscle pH after maximal exercise in man. J Appl Physiol. 1972;32(3):304-8.

29. Fox EL, Bowers RW, Foss ML. The physiological basis of physical education and athletics, 4th ed., New York: Saunders College Publishing; 1988.

30. Rehrer NJ. Fluid and Electrolyte Balance in Ultra-Endurance Sport. Sports Med. 2001;31(10):701-15. 